\title{
The influence of climatic conditions on the efficiency of the solar system
}

\author{
Viacheslav Shemelin and Tomas Matuska \\ University Centre for Energy Efficient Buildings, Czech Technical University in Prague, Trinecka 1024, 27343 Bustehrad, Czech \\ Republic
}

\begin{abstract}
The simulation analysis of the solar hot water preparation system for an apartment building is presented. The analyses investigated the effect of climatic conditions on the efficiency of the solar system. To demonstrate the influence of climatic conditions, four building locations (Stockholm, Prague, Milan, and Barcelona), six different solar collectors, and six different design areas of solar collector field were used. The aim was to verify how the efficiency of the solar system varies depending on the climatic and design conditions. Moreover, the influence of year-to-year fluctuations of climatic conditions was also explored. The analysis has been provided by using TRNSYS simulation software over the period of one year using the time step of 2 minutes. The simulation results clearly showed that the efficiency of the SDHW system is dependent on the climatic conditions, especially on the air temperature. On the other hand, year-to-year weather fluctuations do not strongly affect the efficiency of the SDHW system.
\end{abstract}

\section{Introduction}

Nowadays buildings consume more than $40 \%$ of primary energy all over the world. The major part is spent for hot water production and space heating. Generally, water is heated by burning natural gas, coal or other fossil fuels. However, the use of fossil fuels creates serious environmental problems, including acid emissions, air pollution, and consequent climate changes. This calls for exploring all the possibilities of alternative energy sources that could potentially decrease noxious emissions and reduce the greenhouse effect. In this regard, utilization of solar energy through solar domestic hot water (SDHW) heating systems plays a big role in reducing energy amount required.

SDHW is probably the most popular application of solar system, allowing both fossil fuel savings and emission reductions. Based on the latest reports, $94 \%$ of the energy provided by solar thermal systems worldwide was used for SDHW [1]. The big popularity of these systems is based on the direct conversion of solar energy, relative simplicity of such system and high lifetime of the main components. This is confirmed by the fact that, in the last years the installed capacity of SDHW systems worldwide has increased from $58 \mathrm{GW}_{\text {th }}$ in 2000 to 450 $\mathrm{GW}_{\text {th }}$ at the end of 2018. This corresponds to the annual solar thermal energy yield of $372 \mathrm{TWh}$ in 2018, which correlates to savings of 40 million tons of oil and 129 million tons of $\mathrm{CO}_{2}[1]$.

Many studies analysed different solar hot water preparation system for different climatic conditions. Nikoofard et al. [2] presented an investigation of the technoeconomic feasibility of SDHW system for the
Canadian housing stock. Naspolini and Rüther [3] investigated the technical and economic viability of lowcost SDHW system for residential dwellings on Brazil. In Greece, the feasibility analysis of SDHW system was conducted by Kaldellis et al. [4]. Based on China climate conditions, Chow et al. [5] provided the evaluation of the annual efficiency and the solar fraction of SDHW. Allouhi et al. [6] presented an energy analysis of SDHW for six different climatic zones of Morocco.

These studies give rise to two research questions to be addressed in the remainder of the paper:

1.Is the energy performance of SDWH strongly dependent on climatic conditions?

2. Do the year-to-year fluctuations of climatic conditions for the specific location affect energy efficiency of SDHW?

\section{Solar water heating system}

\subsection{General information}

The influence of climatic conditions on the efficiency of the solar system has been analysed by using TRNSYS simulation software over the period of one year using the time step of 2 minutes.

\subsection{System design}

A schematic diagram of a forced-circulation SDHW system is illustrated in Figure 1. This SDHW system consists of three parts. The first part is the solar part and it consists of solar collector field (SF), supply (SI and SE) 


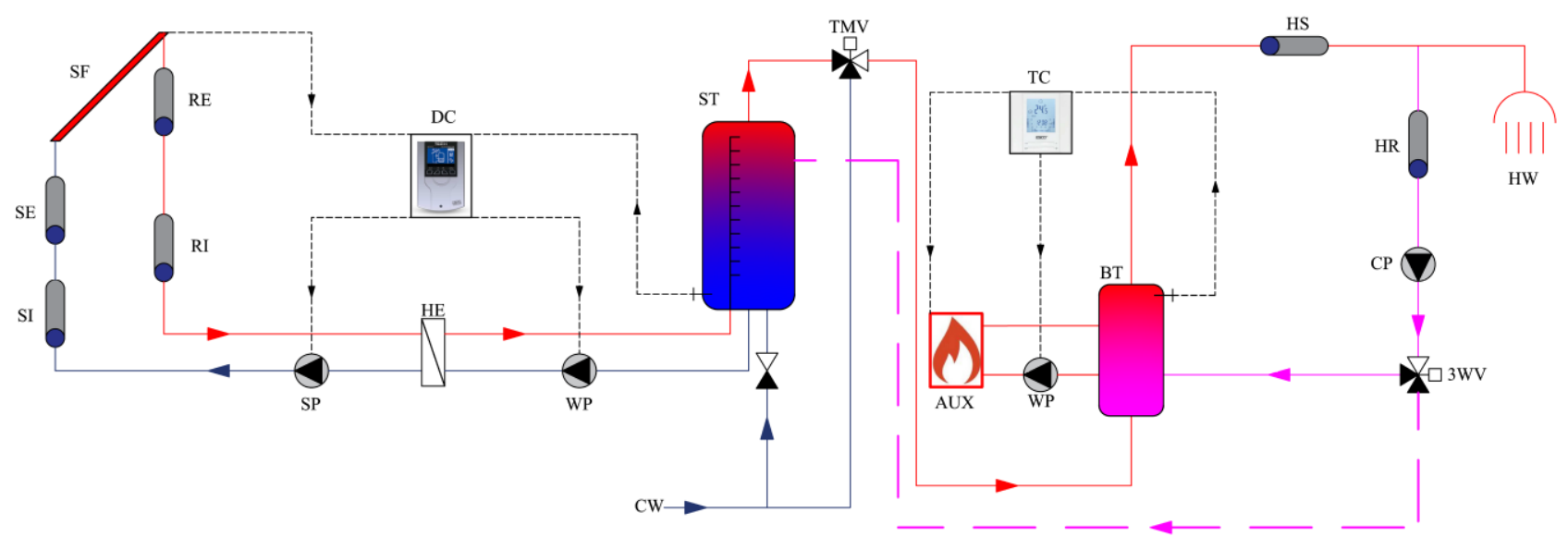

Fig. 1. Schematic of the considered SDHW system.

and returns pipes (RI and RE), solar pump (SP), solar heat exchanger (HE), and differential controller (DC). The second part is the domestic hot water part which includes a solar storage tank (ST), backup hot water tank (BT) with auxiliary heater (AUX), water pump (WP), temperature controller (TC), and a thermostatic mixing valve (TMV) to control the temperature after the solar tank. The third one is recirculation part and it includes supply (HS) and return water circulation pipes (HR), DHW circulation pump (CP), and 3 -way valve ( $3 \mathrm{WV})$ to redirect return circulation water from the backup hot water tank to the solar hot water tank and increase an annual specific solar energy yield of the system. Detailed parameters of the presented SDHW system are listed in Table 1.

Table 1. Detailed parameters of SHDW system.

\begin{tabular}{|c|c|}
\hline Parameter & Description \\
\hline $\begin{array}{l}\text { Building } \\
\text { occupancy }\end{array}$ & 91 persons \\
\hline $\begin{array}{c}\text { Collector } \\
\text { orientation }\end{array}$ & South, slope $45^{\circ}$ \\
\hline $\begin{array}{l}\text { Collector mass } \\
\text { flow rate }\end{array}$ & $151 / \mathrm{m}^{2} \cdot \mathrm{h}$ \\
\hline $\begin{array}{l}\text { Heat transfer } \\
\text { medium }\end{array}$ & Propylene Glycol / Water (50 \% / 50 \%) \\
\hline $\begin{array}{l}\text { Solar pump } \\
\text { control strategy }\end{array}$ & $\begin{array}{l}\text { Pump switching on/off temperature } \\
\text { difference collector-storage } 8 \mathrm{~K} / 2 \mathrm{~K}\end{array}$ \\
\hline Collector piping & $\begin{array}{c}\text { Supply and return pipes are located in } \\
\text { the interior and exterior: } 50 \text { m each, DN } \\
20 \text {, with } 25 \text { mm outside thermal } \\
\text { insulation }\end{array}$ \\
\hline $\begin{array}{l}\text { Heat exchanger } \\
\text { efficiency }\end{array}$ & $\begin{array}{l}\quad 80 \% \text { for } 42{ }^{\circ} \mathrm{C} / 32{ }^{\circ} \mathrm{C} \text { (inlet } \\
\text { temperature/tank storage temperature) }\end{array}$ \\
\hline $\begin{array}{l}\text { Solar tank } \\
\text { volume }\end{array}$ & $50 \mathrm{l} / \mathrm{m}^{2}$ \\
\hline $\begin{array}{l}\text { TMV control } \\
\text { temperature }\end{array}$ & $55^{\circ} \mathrm{C}$ \\
\hline $\begin{array}{l}\text { Backup hot } \\
\text { water tank } \\
\text { volume }\end{array}$ & 5001 \\
\hline
\end{tabular}

Table 1. Continued. Detailed parameters of SHDW system.

\begin{tabular}{|c|c|}
\hline Parameter & Description \\
\hline $\begin{array}{l}\text { Supply and } \\
\text { return water } \\
\text { circulation pipes }\end{array}$ & $\begin{array}{l}173 \mathrm{~m} \text { each, DN } 50 \text {, with } 25 \mathrm{~mm} \text { thermal } \\
\text { insulation }\end{array}$ \\
\hline $3 \mathrm{WV}$ control & $\begin{array}{l}3 \mathrm{WV} \text { valve diverts water from the } \\
\text { backup hot water tank to the solar tank if } \\
\text { the temperature difference between hot } \\
\text { water in the solar tank and return } \\
\text { circulation water is higher than } 3{ }^{\circ} \mathrm{C} \text { and } \\
\text { diverts it back to the backup hot water } \\
\text { tank when the difference becomes lower } \\
\text { than } 0^{\circ} \mathrm{C} \text {. }\end{array}$ \\
\hline
\end{tabular}

\subsection{Weather data}

As previously mentioned, the analysis has been performed for four climatic conditions - Prague, Stockholm, Milan, and Barcelona. The meteorological data were taken from the Meteonorm (TMY) database. The climatic conditions of the considered locations are listed in Table 2.

\subsection{Hot water consumption}

One of the key elements of SDHW dimensioning is the determination of daily hot water consumption. Based on EU statistic data, the average daily domestic hot water consumption varies from 10 litres to 50 litres at $60{ }^{\circ} \mathrm{C}$. This wide range could be described by difference in several parameters like climatic conditions and people habits. An average EU-28 daily domestic hot water consumption is 24 litres at $60{ }^{\circ} \mathrm{C}$ [7]. In the present investigation, an average daily domestic hot water consumption of 401 at $55^{\circ} \mathrm{C}$ per person has been used.

\subsection{Hot water load profile}

In all simulations presented in the study, the characteristic load profile for an apartment building has 
been considered [8]. The daily hot water load profile and profile of circulation operation are presented in Figure 2.

Table 2. Climatic conditions of considered locations (Meteonorm)

\begin{tabular}{|c|c|c|c|c|}
\hline Parameter & $\begin{array}{c}\text { Prague (Czech } \\
\text { Republic) } \\
\end{array}$ & Stockholm (Sweden) & Milan (Italy) & Barcelona (Spain) \\
\hline Latitude & $50.10^{\circ} \mathrm{N}$ & $59.65^{\circ} \mathrm{N}$ & $45.43^{\circ} \mathrm{N}$ & $41.39^{\circ} \mathrm{N}$ \\
\hline $\begin{array}{c}\text { Annual average ambient } \\
\text { temperature }\end{array}$ & $7.9^{\circ} \mathrm{C}$ & $5.3^{\circ} \mathrm{C}$ & $11.7^{\circ} \mathrm{C}$ & $16.27^{\circ} \mathrm{C}$ \\
\hline $\begin{array}{l}\text { Minimum ambient } \\
\text { temperature }\end{array}$ & $-15.2^{\circ} \mathrm{C}$ & $-19.9^{\circ} \mathrm{C}$ & $-7.7^{\circ} \mathrm{C}$ & $0.4^{\circ} \mathrm{C}$ \\
\hline $\begin{array}{l}\text { Maximum ambient } \\
\text { temperature }\end{array}$ & $30.7^{\circ} \mathrm{C}$ & $28.3^{\circ} \mathrm{C}$ & $32.1^{\circ} \mathrm{C}$ & $31.3^{\circ} \mathrm{C}$ \\
\hline $\begin{array}{l}\text { Global solar horizontal } \\
\text { irradiation }\end{array}$ & $999 \mathrm{kWh} / \mathrm{m}^{2}$ & $981 \mathrm{kWh} / \mathrm{m}^{2}$ & $1255 \mathrm{kWh} / \mathrm{m}^{2}$ & $1446 \mathrm{kWh} / \mathrm{m}^{2}$ \\
\hline $\begin{array}{l}\text { Global solar irradiation on } \\
\left.\text { tilted surface (South, } 45^{\circ}\right)\end{array}$ & $1114 \mathrm{kWh} / \mathrm{m}^{2}$ & $1231 \mathrm{kWh} / \mathrm{m}^{2}$ & $1392 \mathrm{kWh} / \mathrm{m}^{2}$ & $1629 \mathrm{kWh} / \mathrm{m}^{2}$ \\
\hline
\end{tabular}

The cold water temperature considered in the analysis was $10{ }^{\circ} \mathrm{C}$ and is constant during the year. The hot water is provided at temperature of $55^{\circ} \mathrm{C}$. Annual heat energy demand without heat losses is $67.6 \mathrm{MWh} / \mathrm{a}$. The total annual heat energy demand (including heat losses of hot water distribution system) is $119 \mathrm{MWh} / \mathrm{a}$.

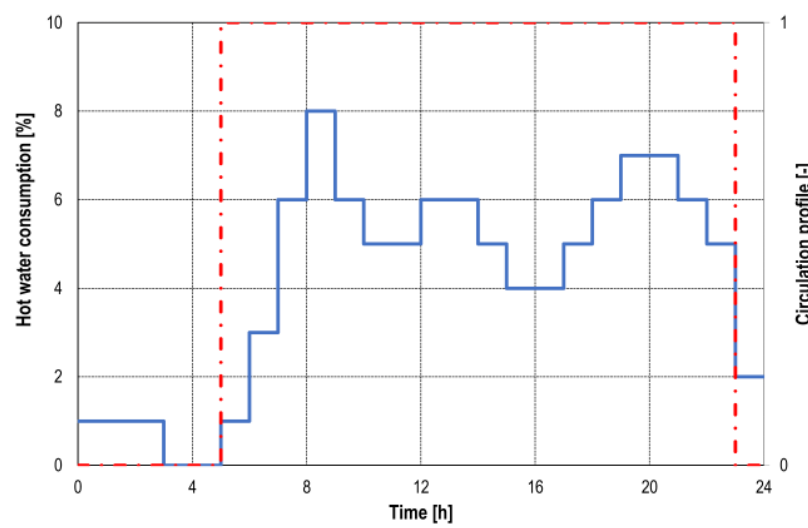

Fig. 2. Daily hot water profile and circulation operation profile.

\subsection{Solar thermal collectors}

A mathematical modelling of solar thermal collectors is based on the standard second-order collector performance equation expressed as

$$
\eta=\eta_{0}-a_{1} \frac{T_{\mathrm{m}}-T_{\mathrm{a}}}{G}-a_{2} \frac{\left(T_{\mathrm{m}}-T_{\mathrm{a}}\right)^{2}}{G}
$$

where $\eta_{0}$ parameter indicates the optical efficiency of the collector [-]; $a_{1}\left[\mathrm{~W} / \mathrm{m}^{2} \mathrm{~K}\right]$ and $a_{2}\left[\mathrm{~W} / \mathrm{m}^{2} \mathrm{~K}^{2}\right]$ represents the thermal loss parameters. $G$ is the incident solar irradiance $\left[\mathrm{W} / \mathrm{m}^{2}\right], T_{\mathrm{m}}$ is the fluid mean temperature across the solar collector $[\mathrm{K}]$ and $T_{\mathrm{a}}$ is the ambient temperature [K].

In the present study, six different flat plate solar collectors were chosen. In Table 3 are listed the characterizing parameters of the selected solar thermal collectors related to the gross area of the collectors.

\subsection{Solar thermal collectors}

In order to analyse the effect of climatic conditions on the efficiency of the solar system, six different solar collector field areas in the range between 0.25 and $1.5 \mathrm{~m}^{2}$ of solar collectors per person were chosen.

Table 3. Collector performance characteristics.

\begin{tabular}{|c|c|c|c|}
\hline Collector & $\eta_{\mathbf{0}}[-]$ & $\boldsymbol{a}_{1}\left[\mathbf{W} / \mathbf{m}^{2} \mathbf{K}\right]$ & $\boldsymbol{a}_{2}\left[\mathbf{W} / \mathbf{m}^{2} \mathbf{K}^{2}\right]$ \\
\hline 1 & 0.702 & 3.930 & 0.007 \\
\hline 2 & 0.737 & 3.128 & 0.010 \\
\hline 3 & 0.728 & 3.055 & 0.014 \\
\hline 4 & 0.754 & 3.669 & 0.012 \\
\hline 5 & 0.769 & 3.411 & 0.010 \\
\hline 6 & 0.749 & 3.040 & 0.006 \\
\hline
\end{tabular}

\section{Energy performance}

The SDHW system performance is evaluated using efficiency of solar system $\eta_{s s}$ [-]. System efficiency is defined as the total useful solar energy delivered to the building $Q_{s s, u}$ divided by the total energy incident on the collector filed $Q_{s}$ :

$$
\eta_{\mathrm{ss}}=\frac{Q_{\mathrm{ss}, \mathrm{u}}}{Q_{\mathrm{s}}}=\frac{Q_{\mathrm{ss}, \mathrm{u}}}{H_{\mathrm{T}} A}=\frac{q_{\mathrm{ss}, \mathrm{u}}}{H_{\mathrm{T}}}
$$

where $H_{T}$ is total solar energy yield on the collector surface $\left[\mathrm{kWh} / \mathrm{m}^{2} \mathrm{a}\right], A$ is the area of collector field $\left[\mathrm{m}^{2}\right], q_{\mathrm{ss}}$ is an annual specific solar energy yield $\left[\mathrm{kWh} / \mathrm{m}^{2} \mathrm{a}\right]$. 
Annual specific solar energy yield describes the annual amount of usable heat supplied to load the from $1 \mathrm{~m}^{2}$ of collector surface area

$$
q_{\mathrm{ss}, \mathrm{u}}=\frac{Q_{\mathrm{ss}, \mathrm{u}}}{A}
$$

\section{Results and discussion}

\subsection{Influence of climatic conditions}

To demonstrate the influence of climatic conditions on the efficiency of DHW system, four different locations (Stockholm, Prague, Milan, and Barcelona), six different flat plate collectors, and six different design areas of solar collector field were chosen for comprehensive analysis. The SDHW system efficiency for every case was determined by detailed simulation in TRNSYS. The results of the simulation for the collector alternatives 1 and 6 are shown in Table 4. The simulation results for the other collector variants are identical. The results of the simulation for all collector alternatives (coloured dots) are shown in Figure 3.

Firstly, the results of the simulation indicate that the efficiency of solar system is dependent on the climatic conditions or, to be more precise, on the ambient air temperature. On the one hand, it is evident, that the colder climate cases higher heat losses of the outdoor part of the solar system and therefore lower efficiency of the whole system. On the other hand, in the well-insulated SDHW system the influence of the heat losses could be minimised and, as a result, the influence of climatic conditions could be also minimised.

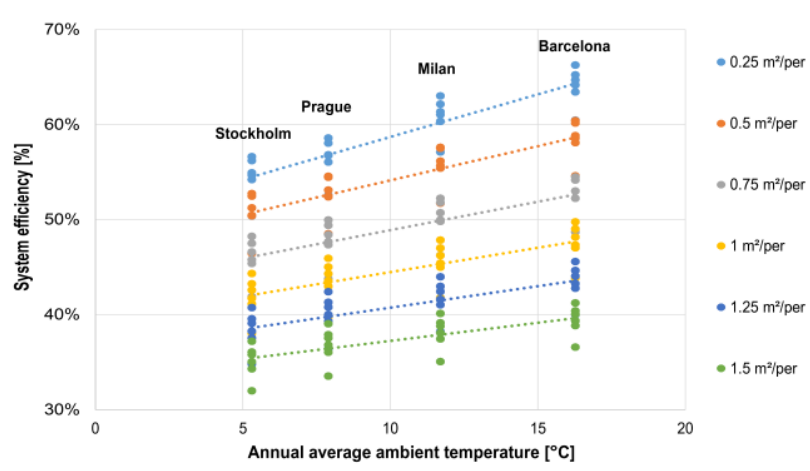

Fig. 3. Annual efficiency of considered SDHW systems.

Secondly, the mean system efficiency for the different areas of solar collector field could be calculated based on the simulation results. Figure 4 shows the mean system efficiency as a function of solar collector field area. It is important to note that the efficiency value varies in the range between $37 \%$ and $59 \%$. Moreover, this figure may be further used for the quick estimation of an annual specific solar energy yield of the solar thermal system in Europe.

Table 4. The simulation results of the annual efficiency for the collector alternatives 1 and 6 .

\begin{tabular}{|c|c|c|c|c|}
\hline $\begin{array}{c}\text { Specific solar collector } \\
\text { area }\left[\mathrm{m}^{2} / \mathrm{per}\right]\end{array}$ & $\begin{array}{c}\text { Prague (Czech } \\
\text { Republic) }\end{array}$ & Stockholm (Sweden) & Milan (Italy) & Barcelona (Spain) \\
\hline \multicolumn{5}{|c|}{ Collector 1} \\
\hline 0.25 & $53 \%$ & $50 \%$ & $57 \%$ & $60 \%$ \\
\hline 0.50 & $49 \%$ & $46 \%$ & $52 \%$ & $55 \%$ \\
\hline 0.75 & $44 \%$ & $42 \%$ & $46 \%$ & $49 \%$ \\
\hline 1.00 & $40 \%$ & $38 \%$ & $42 \%$ & $44 \%$ \\
\hline 1.25 & $36 \%$ & $35 \%$ & $38 \%$ & $40 \%$ \\
\hline 1.50 & $34 \%$ & $32 \%$ & $35 \%$ & $37 \%$ \\
\hline \multicolumn{5}{|c|}{ Collector 6} \\
\hline 0.25 & $58 \%$ & $56 \%$ & $62 \%$ & $65 \%$ \\
\hline 0.50 & $55 \%$ & $53 \%$ & $58 \%$ & $60 \%$ \\
\hline 0.75 & $50 \%$ & $48 \%$ & $52 \%$ & $54 \%$ \\
\hline 1.00 & $46 \%$ & $44 \%$ & $48 \%$ & $50 \%$ \\
\hline 1.25 & $42 \%$ & $41 \%$ & $44 \%$ & $46 \%$ \\
\hline 1.50 & $39 \%$ & $37 \%$ & $40 \%$ & $41 \%$ \\
\hline
\end{tabular}




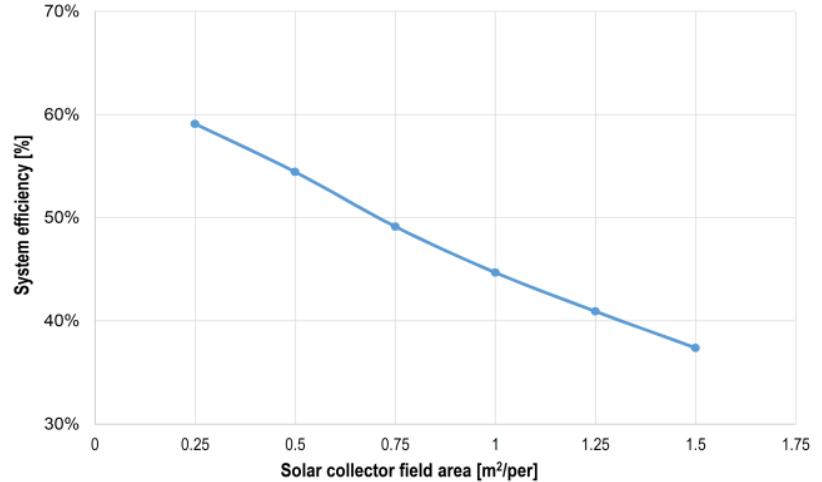

Fig. 4. The mean calculated efficiency values for the different solar collector field areas.

Finally, it can be observed that the efficiency of the solar system is strongly influenced by the ratio between solar collector area and heat demand, here represented as a number of occupants. The higher this value is, the higher mean water temperature in the solar tank is, consequently, the operation temperature in the collector field is higher, and finally, the collector field operates with lower efficiency and the SDHW efficiency is lower. Moreover, the high value of solar collector field area may cause frequent stagnation in summer period and, as a result, unused solar gains during the summer. This leads to decrease in the annual energy yield of the solar system, and, as a result, to lower efficiency of whole SDHW system.

\subsection{Year-on-year weather fluctuations}

To demonstrate the influence of year-to-year fluctuations of climatic conditions on the efficiency of SDHW system, the simulation analysis was provided for Prague climate conditions, for solar collector field of $1 \mathrm{~m}^{2} / \mathrm{per}$ and for solar collector variant 3 . The hourly climatic data from 2007 to 2016 used in the analysis were taken from PVGIS weather database and compared with reference climatic year for Prague (RCY, Czech Hydrometeorological Institute) and typical meteorological year (TMY, Meteonorm). The results of the simulation are shown in Table 5 and in Figure 5.

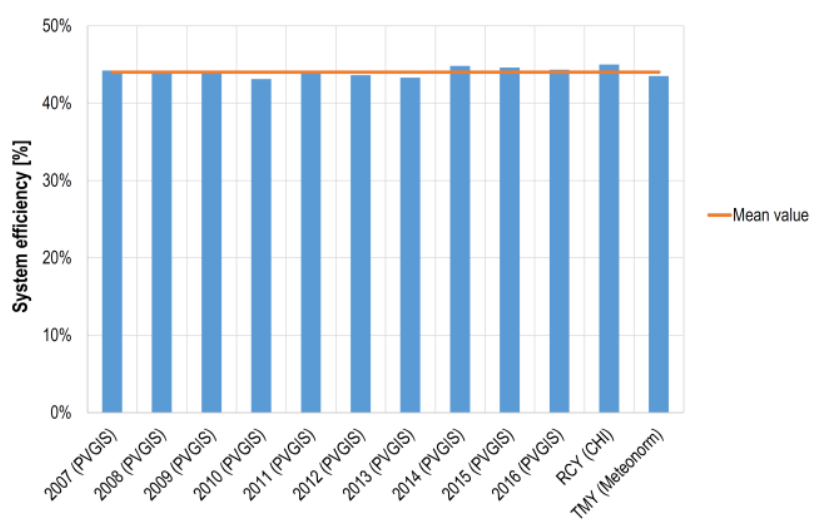

Fig. 5. The influence of year-to-year climate fluctuations on the efficiency of SDHW system.

Using the data gathered, one may support that the efficiency of the considered solar system is not strongly dependent on the year-to-year fluctuations of climatic

Table 5. The simulation results of the annual efficiency of SDHW system for individual years.

\begin{tabular}{|c|c|c|c|c|}
\hline Climate data & $\boldsymbol{T}_{\mathrm{a}, \mathrm{av}}\left[{ }^{\circ} \mathbf{C}\right]$ & $H_{\mathrm{T}}\left[\mathrm{kWh} / \mathbf{m}^{2} \mathbf{a}\right]$ & $q_{\mathrm{ss}, \mathrm{u}}\left[\mathrm{kWh} / \mathbf{m}^{2} \mathbf{a}\right]$ & $\eta_{\mathrm{ss}}[\%]$ \\
\hline 2007 (PVGIS) & 10.4 & 1229 & 543 & 44.2 \\
\hline 2008 (PVGIS) & 10.1 & 1199 & 529 & 44.1 \\
\hline 2009 (PVGIS) & 9.8 & 1194 & 524 & 43.9 \\
\hline 2010 (PVGIS) & 8.5 & 1200 & 517 & 43.1 \\
\hline 2011 (PVGIS) & 10.0 & 1339 & 587 & 43.8 \\
\hline 2012 (PVGIS) & 9.7 & 1321 & 576 & 43.6 \\
\hline 2013 (PVGIS) & 9.4 & 1166 & 505 & 43.3 \\
\hline 2014 (PVGIS) & 10.8 & 1219 & 547 & 44.8 \\
\hline 2015 (PVGIS) & 10.9 & 1297 & 578 & 44.6 \\
\hline 2016 (PVGIS) & 10.1 & 1233 & 546 & 44.3 \\
\hline $\mathrm{RCY}(\mathrm{CHI})$ & 10.4 & 1215 & 546 & 45.0 \\
\hline TMY (Meteonorm) & 7.9 & 1114 & 485 & 43.5 \\
\hline
\end{tabular}


conditions. According to the simulation results, the mean SDHW efficiency value is $44 \%$. The highest efficiency value of $45 \%$ demonstrated SDHW system simulated using the reference climatic year (RCY, Czech Hydrometeorological Institute), which had been calculated according to measured data from the last decade. On the other hand, the lowest efficiency of 43.5 showed SDHW system simulated using the typical meteorological year (TMY, Meteonorm). Moreover, it is also important to note that the TMY, which is commonly used in simulation software, also demonstrated the lowest annual ambient temperature $T_{\mathrm{a}, \mathrm{av}}$, the lowest total solar energy yield on the collector surface $H_{\mathrm{T}}$, and consequently the lowest annual specific solar energy yield $q_{\mathrm{ss}, \mathrm{u}}$.

\section{Conclusion}

Detailed simulation analysis of the influence of climatic conditions on the efficiency of SDHW system has been provided. To demonstrate the influence of climatic conditions, four different locations across Europe, six different collectors and six different areas of solar collector field have been investigated. Based on the simulation results, the following can be concluded:

- The efficiency of solar system is dependent on the climatic conditions. The main parameter which affects the efficiency of the solar system is an ambient air temperature,

- The efficiency of the solar system is strongly dependent on the ratio between area of solar collector field and heat demand. The higher ratio is, the lower is annual efficiency of the SDHW system. The efficiency values for the different design conditions, different collector alternatives, and different climate conditions vary in the range between $37 \%$ and $59 \%$,

- The year-to-year fluctuations of climatic conditions at given location do not strongly affect the efficiency of SDHW system. According the simulation results, the mean SDHW efficiency value for Prague climate is $44 \%$ with a variation of maximum $1 \%$ due to climatic fluctuations. The design conditions have much stronger impact than climatic conditions fluctuation.

This work has been supported by the Ministry of Education, Youth and Sports within National Sustainability Programme I, project No. LO1605.

\section{References}

1. W. Weiss, M. Spörk-Dür, Solar heat worldwide (IEA Solar Heating \& Cooling Programme, 2019)

2. S. Nikoofard, V. I. Ugursal, I. Beausoleil-Morrison, Sol. Energy 101, 308 (2014)

3. H. F. Naspolini, R. Rüther, Renew. Energy 48, 92 (2012)

4. J. K. Kaldellis, K. El-Samani, P. Koronakis, Renew. Energy 30, 659 (2005)
5. T. T. Chow, K. F. Fong, A. L. S. Chan, Z. Lin, Appl. Energy 83, 42 (2006)

6. A. Allouhi, A. Jamil, T. Kousksou, T. El Rhafiki, Y. Mourad, Y. Zeraouli, Energy Convers. Manag. 92, 105 (2015)

7. R. Kemna, M van Elburg, W. Li, R. van Holsteijn, Eco-design of Boilers, Task 1, Final (VHK for European Comission, 2007)

8. EN 12831-3:2017, Energy performance of buildings-Method for calculation of the design heat load-Part 3: Domestic hot water systems heat load and characterisation of needs, (2017) 